\title{
PENENTU KESEHATAN PERBANKAN
}

\section{YULIUS KURNIA SUSANTO dan TJHAI FUNG NJIT}

\author{
STIE TRISAKTI \\ yulius@stietrisakti.ac.id
}

\begin{abstract}
Abstrak: This research aims to provide empirical evident about determinant on banking healthy using the CAMEL (capital, assets, management, earnings and liquidity) method. CAMEL is one method to evaluate the banking performance. Sample are used in this research all company of state own bank, foreign exchange bank, and non-foreign exchange bank from the directory from 2005 until 2007 using purposive sampling method. The result of this research shows that nonperformance loan, return on equity, loan to deposit ratio and reserve requirement have determinant on banking healthy.
\end{abstract}

Keywords: CAMEL, Bankruptcy, Financial distress.

\section{PENDAHULUAN}

Keberadaan dunia perbankan di satu sisi dalam sistem ekonomi akan memperlancar arus dana kesektor produktif yang dapat menggairahkan kegiatan ekonomi masyarakat. Di sisi lain, dunia perbankan sebagai entitas bisnis juga dituntut dapat beroperasi sedemikian rupa sehingga terjamin kelangsungan hidupnya. Untuk mempertahankan kelangsungan hidup dalam sistem keuangan yang turbulen, sebuah bank harus dapat berkompetisi dengan bank-bank kompetitor dan financial intermediary unit lainnya yang juga memberikan layanan jasa keuangan yang lebih baik dari kompetitornya.

Untuk menilai kinerja perusahan perbankan umumnya digunakan lima aspek penilaian, yaitu Capital, Asset, Management, Earnings dan Liquidity yang biasa disebut CAMEL. Aspek-aspek tersebut menggunakan rasio keu- 
angan, hal ini menunjukkan bahwa rasio keuangan dapat digunakan untuk penilaian tingkat kesehatan bank dan menunjukkan bahwa rasio keuangan bermanfaat dalam menilai kondisi keuangan perusahaan perbankan.

Secara empiris tingkat kegagalan bisnis dan kebangkrutan bank dengan menggunakan rasio-rasio keuangan model CAMEL dapat diuji sebagaimana yang telah dilakukan Aryati dan Manao (2002) mengunakan rasio keuangan sebagai prediktor Bank bermasalah di Indonesia. Siswantoro (2004) meneliti tentang karakteristik bank likuidasi dan restrukturisasi di Indonesia. Selain itu, Trihartanto dan Kurniawan (2005) menyatakan bahwa tidak semua rasio keuangan yang telah diteliti Altman bisa digunakan dalam model fungsi logistik untuk membedakan kesehatan Bank di Indonesia.

Penelitian ini merupakan pengembangan penelitian Almilia dan Winny (2005) yang menggunakan sampel 16 bank sehat, 2 bank yang mengalami kebangkrutan dan 6 bank yang mengalami kondisi kesulitan keuangan periode 2000 sampai 2002. Penelitian ini menunjukkan bahwa rasio CAMEL memiliki daya klasifikasi atau daya prediksi untuk kondisi bank yang mengalami kesulitan keuangan dan bank yang mengalami kebangkrutan. Perbedaan penelitian ini dengan penelitian Almilia dan Winny (2005) adalah penambahan variabel giro wajib minimum (GWM). Motivasi dari peneliti untuk menambah variabel giro wajib minimum (GWM) karena GWM merupakan ketentuan bagi setiap bank umum untuk menyisihkan sebagian dari dana pihak ketiga yang berhasil dihimpunnya dalam bentuk giro wajib minimum yang berupa rekening giro bank yang bersangkutan pada Bank Indonesia.

Tujuan penelitian adalah untuk mendapatkan bukti empiris bahwa CAR (Capital Adequancy Ratio), ATTM (Aktiva Tetap Terhadap Modal), APB (Aktiva Produktif Bermasalah), NPL (Non Performing Loan), PPAPAP (Penyisihan Penghapusan Aktiva Produktif Terhadap Aktiva Produktif), Pemenuhan PPAP (Penyisihan Penghapusan Aktiva Produktif), ROA (Return On Assets), ROE (Return On Equity), NIM (Net Interest Margin), BOPO (Biaya Operasional terhadap Pendapatan Operasional), LDR (Loan to Deposit Ratio) dan GWM (giro wajib minimum) berpengaruh terhadap Kesehatan Perbankan.

Penelitian Almilia dan Winny (2005) menunjukkan bahwa rasio CAR memiliki pengaruh terhadap prediksi kondisi bermasalah bank. Sedangkan penelitian Aryati dan Hekinus (2002) menunjukkan bahwa rasio CAR dapat membedakan bank sehat dan tidak sehat. Penelitian Almilia dan Winny (2005) menunjukkan bahwa rasio ATTM tidak memiliki perbedaan antara bank bermasalah dan bank tidak bermasalah. 
Penelitian Almilia dan Winny (2005) menunjukkan bahwa rasio APB tidak memiliki pengaruh terhadap kondisi bermasalah suatu bank. Penelitian Mabruroh (2004) menunjukkan bahwa rasio NPL mempunyai pengaruh positif terhadap kinerja keuangan perbankan. Tetapi penelitian pernah dilakukan oleh Almilia dan Winny (2005) menggunakan rasio yang sama NPL untuk melihat apakah rasio NPL memiliki pengaruh terhadap kondisi bermasalah suatu bank dan hasilnya menunjukkan bahwa NPL tidak memiliki pengaruh terhadap kondisi bermasalah suatu bank. NPL diprediksikan semakin tinggi maka akan semakin buruk kualitas kredit bank yang menyebabkan jumlah kredit bermasalah semakin besar maka kemungkinan suatu bank dalam kondisi bermasalah semakin besar.

Penelitian Almilia dan Winny (2005) menunjukkan bahwa rasio PPAPAP memiliki perbedaan antara bank bermasalah dan bank tidak bermasalah. Penelitian Almilia dan Winny (2005) menunjukkan bahwa rasio pemenuhan PPAP tidak memiliki pengaruh terhadap kondisi bermasalah suatu bank.

Hasil penelitian Haryati (2002) menunjukkan bahwa ROA memiliki hubungan positif dengan kinerja keuangan. Aryati dan Hekinus (2002) juga meneliti pengaruh Return On Asset terhadap keberhasilan atau kegagalan suatu bank dan hasilnya terdukung. Penelitian Mabruroh (2004) menunjukkan bahwa rasio ROE tidak berpengaruh terhadap kinerja keuangan perbankan. Penelitian Almilia dan Winny (2005) menunjukkan bahwa rasio ROE tidak memiliki pengaruh terhadap kondisi bermasalah suatu bank.

Penelitian Mabruroh (2004) menunjukkan bahwa Rasio NIM mempunyai pengaruh positif terhadap kinerja keuangan perbankan. Tetapi penelitian yang dilakukan menunjukkan rasio NIM tidak berpengaruh terhadap kondisi bermasalah suatu bank. Penelitian Mabruroh (2004) menunjukkan bahwa rasio BOPO mempunyai pengaruh negatif terhadap kinerja keuangan perbankan. Penelitian Nasser dan Titik (2000) menunjukkan BOPO tidak dapat membedakan antara bank sehat dengan bank yang gagal.

Penelitian Mabruroh (2004) menunjukkan bahwa rasio LDR mempunyai pengaruh positif terhadap kinerja keuangan perbankan. Tetapi berbeda sebaliknya pada penelitian Nasser dan Titik (2000) menunjukkan LDR tidak dapat membedakan antara bank sehat dengan bank yang gagal. Penelitian Mabruroh (2004) melihat apakah giro wajib minimum memiliki pengaruh terhadap kinerja keuangan perbankan ternyata pengujian terhadap variabel giro wajib minumum menunjukkan bahwa giro wajib minimum mempunyai pengaruh positif terhadap kinerja keuangan perbankan. 


\section{METODA PENELITIAN}

\section{Pemilihan Sampel dan Pengumpulan Data}

Obyek penelitian ini merupakan bank-bank yang terdaftar pada Direktori Perbankan Indonesia yang terdiri dari bank Persero, bank umum swasta nasional devisa, dan bank umum swasta nasional non devisa pada tahun 2005, 2006 dan 2007. Proses pemilihan sampel sebagai berikut:

Tabel 1 Proses Pemilihan Sampel

\section{Kriteria}

Perusahaan

Perbankan

1. Perusahaan Perbankan seperti Bank Persero, Bank Umum Swasta Nasional Devisa dan Bank Umum Swasta Nasional non Devisa pada tahun 2005, 2006 dan 2007.

2. Perbankan yang termasuk Bank Syariah.

3. Perusahaan Perbankan yang bangkrut pada tahun 2005, 2006 dan 2007.

Jumlah perusahaan perbankan yang dijadikan sampel

\section{Definisi Operasional dan Pengukuran Variabel}

Pengukuran Kesehatan Perbankan menggunakan variabel dummy, kondisi bank yang sehat diberi nilai 1 dan untuk kondisi bank yang tidak sehat dinyatakan dalam kategori 0 . Bank tidak sehat dikriteriakan seperti memiliki nilai NPL lebih dari 5\% (Surifah 2002). LDR di atas nilai 110\% dan BOPO di atas 100\%. (Dendawijaya 2005).

CAR merupakan rasio equity yang diklasifikasikan terhadap jumlah kredit yang disalurkan, yang menunjukkan kemampuan permodalan dan cadangan yang digunakan untuk menunjang kegiatan operasi perusahaan. Perhitungannya yang diperoleh dengan membandingkan modal sendiri dengan aktiva tertimbang menurut risiko yang dihitung dari bank yang bersangkutan (Almilia dan Winny 2005). Rumus yang digunakan:

$$
\mathrm{CAR}=\frac{\text { Modal bank }}{\text { Total ATMR }} \times 100 \%
$$

Keterangan:

Modal bank $=$ Modal inti + Modal Pelengkap

ATMR = Aktiva Tertimbang Menurut Risiko, ATMR kredit + ATMR pasar 
ATTM, semakin tinggi rasio ini artinya modal yang dimiliki bank kurang mencukupi dalam menunjang aktiva tetap dan inventaris sehingga kemungkinan suatu bank dalam kondisi bermasalah akan semakin besar. Perhitungannya yang diperoleh dengan membandingkan aktiva tetap dan inventaris dengan modal (Almilia dan Winny 2005). Rumus yang digunakan:

$$
\text { ATTM }=\frac{\text { Aktiva Tetap dan Inventaris }}{\text { Modal }} \times 100 \%
$$

APB adalah aktiva produktif dengan kualitas kurang lancar, diragukan dan macet. Perhitungannya yang diperoleh dengan membandingkan aktiva produktif bermasalah dengan total aktiva produktif (Almilia dan Winny 2005). Rumus yang digunakan:

$$
\mathrm{APB}=\frac{\text { Aktiva produktif Bermasalah }}{\text { Total Aktiva Produktif }} \times 100 \%
$$

NPL mengukur seberapa besar kredit macet yang harus diantisipasi oleh bank. Semakin besar rasio ini, berarti semakin buruk bank dalam pengelolan aktivanya. Perhitungannya yang diperoleh dengan membandingkan kredit bermasalah dengan total kredit (Almilia dan Winny 2005). Rumus yang digunakan:

$$
\text { NPL }=\frac{\text { Kredit Bermasalah }}{\text { Total Kredit }} \times 100 \%
$$

PPAPAP diukur dengan membandingkan Penyisihan Penghapusan Aktiva Produktif yang telah dibentuk dengan total aktiva produktif (Almilia dan Winny 2005). Rumus yang digunakan:

$$
\text { PPAP terhadap Aktiva produktif }=\frac{\text { PPAP yang telah dibentuk }}{\text { Total Aktiva Produktif }} \times 100 \%
$$

Pemenuhan PPAP diukur dengan membandingkan Penyisihan Penghapusan Aktiva Produktif yang telah dibentuk dengan Penyisihan Penghapusan Aktiva Produktif wajib dibentuk (Almilia dan Winny 2005). Rumus yang digunakan:

$$
\text { Pemenuhan PPAP }=\frac{\text { PPAP yang telah dibentuk }}{\text { PPAP wajib dibentuk }} \times 100 \%
$$


Rasio ROA digunakan untuk menggambarkan produktivitas bank (berapa banyak kekayaan yang harus dikumpulkan dan dipakai untuk menghasilkan sejumlah tertentu laba). Semakin besar nilai rasio ini menunjukkan bahwa bank semakin produktif. Perhitungannya yang diperoleh dengan membandingkan laba sebelum pajak dengan rata-rata total asset (Almilia dan Winny 2005). Rumus yang digunakan:

$$
\text { ROA }=\frac{\text { Laba sebelum Pajak }}{\text { Rata-rata total asset }} \times 100 \%
$$

Rasio ROE menggambarkan kinerja bank dalam hal menghasilkan pendapatan. Perhitungannya yang diperoleh dengan membandingkan laba setelah pajak dengan rata-rata ekuitas (Almilia dan Winny 2005). Rumus yang digunakan:

$$
\mathrm{ROE}=\frac{\text { Laba setelah pajak }}{\text { Rata-rata ekuitas }} \times 100 \%
$$

NIM menggambarkan pendapatan bunga bersih dibandingkan dengan rata-rata aktiva produktif (Almilia dan Winny 2005). Rumus yang digunakan:

$$
\mathrm{NIM}=\frac{\text { Pendapatan bunga bersih }}{\text { Aktiva Produktif }} \times 100 \%
$$

BOPO merupakan rasio yang digunakan untuk mengukur tingkat dan distribusi bank dalam melakukan kegiatan operasinya, semakin kecil rasio ini menunjukkan manajemen bank semakin baik. Perhitungannya yang diperoleh dengan membandingkan biaya operasioanl dengan pendapatan operasional (Almilia dan Winny 2005). Rumus yang digunakan:

$$
\text { BOPO }=\frac{\text { Biaya Operasional }}{\text { Pendapatan Operasional }} \times 100 \%
$$

LDR diperoleh dari perhitungan dengan membandingkan antara seluruh penempatan dan seluruh dana yang berhasil dihimpun ditambah dengan modal sendiri atau membandingkan total kredit dengan total dana pihak ketiga (Almilia dan Winny 2005). Rumus yang digunakan: 


$$
\text { LDR }=\frac{\text { Total Kredit }}{\text { Total Dana Pihak Ketiga }} \times 100 \%
$$

GWM perhitungannya yang diperoleh dengan membandingkan giro pada Bank Indonesia dengan seluruh dana yang berhasil dihimpun atau membandingkan jumlah alat likuid yang terdiri dari kas dan giro pada Bank Indonesia dengan jumlah dana pihak ketiga yang terdiri dari giro, deposito berjangka, sertifikat deposito, tabungan dan kewajiban jangka pendek lainnya (Mabruroh 2004). Rumus yang digunakan:

$$
\mathrm{GWM}=\frac{\text { Jumlah alat likuid }}{\text { Jumlah dana pihak ketiga }} \times 100 \%
$$

\section{HASIL DAN PEMBAHASAN}

Statistika deskriptif disajikan pada tabel dibawah ini:

Tabel 2 Statistik Deskriptif

\begin{tabular}{lccccc}
\hline \multicolumn{1}{c}{ Variabel } & $\mathbf{n}$ & Mean & Std.Deviation & Minimum & Maximum \\
\hline KESEHATAN & 198 & 0,692 & 0,463 & 0 & 1 \\
CAR & 198 & 35,2732 & 102,58406 & 8,07 & 380,92 \\
ATTM & 198 & 32,9975 & 27,11352 & 0,28 & 233,38 \\
APB & 198 & 2,6832 & 3,78663 & 0 & 40 \\
PPAPAP & 198 & 1,657 & 1,10971 & 0,06 & 6,72 \\
PPAP & 198 & 123,616 & 41,97659 & 79,41 & 376,47 \\
NPL & 198 & 4,233 & 5,93415 & 0 & 63 \\
ROA & 198 & 1,5886 & 2,63429 & $-15,56$ & 15,04 \\
ROE & 198 & 8,4422 & 19,30345 & $-132,46$ & 49,31 \\
NIM & 198 & 6,6498 & 3,74125 & $-5,39$ & 32,95 \\
BOPO & 198 & 88,6081 & 23,49493 & 4,4 & 273,49 \\
LDR & 198 & 95,9685 & 219,21277 & 21,35 & 2802,94 \\
GWM & 198 & 8,252 & 2,85846 & 4,96 & 24,5 \\
\hline
\end{tabular}


Pengujian hipotesis yang menggunakan binary logistic regression, sebelumnya dilakukan uji kelayakan model regresi dilihat dari pertama, nilai Hosmer and lemeshow's adalah 8,786 dengan p-value 0,361>0,05, artinya model mampu memprediksi nilai obeservasinya atau dapat dikatakan goodness fit model. Kedua, nilai -2logLikelihood yaitu model pertama untuk yang hanya memasukkan konstanta dan model kedua memasukkan konstanta dan variabel bebas. Model regresi ini layak digunakan karena angka -2log Likelihood pada Block Number=0 sebesar 244,552 turun menjadi 90,491 pada Block Number=1, penurunan ini menunjukkan model regresi yang lebih baik (Ghozali 2005).

Hasil uji ketepatan prediksi ditunjukkan pada Tabel 3 di bawah ini:

Tabel 3 Uji ketepatan Prediksi

\begin{tabular}{lcccc}
\hline \multirow{2}{*}{ Observed } & \multicolumn{3}{c}{ Predicted } \\
\cline { 2 - 4 } & \multicolumn{2}{c}{ Kesehatan } & Percentage \\
\cline { 2 - 4 } & tidak sehat & sehat & Correct \\
\hline \multirow{2}{*}{ Kesehatan } & tidak sehat & 49 & 12 & 80.3 \\
& sehat & 8 & 129 & 94.2 \\
Overall Percentage & & & 89,9 \\
\hline
\end{tabular}

Menurut observasi ada 61 Bank yang tidak sehat tetapi menurut hasil prediksi yang tidak sehat adalah 49 Bank sehingga nilai ketepatan Bank yang tidak sehat adalah 80,3 persen (49 dibagi 61). Sedangkan untuk Bank yang sehat ada 137 Bank tetapi hasil prediksi ada 129 Bank yang sehat sehingga ketepatan Bank yang sehat adalah sebesar 94,2 persen (129 dibagi 137). Secara keseluruhan ketepatan klasifikasi adalah 89,9 persen (178 dibagi 198).

Hasil pengujian dapat dilihat dalam Tabel 4 berikut ini: 
Tabel 4 Hasil Penentu Kesehatan Perbankan

\begin{tabular}{lrrrrr}
\hline Variabel & \multicolumn{1}{c}{ B } & S.E. & Wald & Sig. & \multicolumn{1}{c}{ Exp(B) } \\
\hline Konstanta & 15,332 & 4,192 & 13,378 & 0,000 & 4557993,482 \\
CAR & $-0,004$ & 0,003 & 2,320 & 0,128 & 0,996 \\
ATTM & 0,005 & 0,017 & 0,083 & 0,773 & 1,005 \\
APB & 0,760 & 0,624 & 1,481 & 0,224 & 2,137 \\
PPAPAP & $-0,123$ & 0,344 & 0,127 & 0,722 & 0,885 \\
PPAP & $-0,004$ & 0,007 & 0,281 & 0,596 & 0,996 \\
NPL & $-1,602$ & 0,479 & 11,172 & 0,001 & 0,202 \\
ROA & 0,105 & 0,295 & 0,127 & 0,721 & 1,111 \\
ROE & 0,203 & 0,071 & 8,151 & 0,004 & 1,225 \\
NIM & 0,127 & 0,148 & 0,742 & 0,389 & 1,136 \\
BOPO & $-0,011$ & 0,027 & 0,156 & 0,692 & 0,989 \\
LDR & $-0,101$ & 0,030 & 11,127 & 0,001 & 0,904 \\
GWM & $-0,461$ & 0,175 & 6,972 & 0,008 & 0,631 \\
\hline
\end{tabular}

Dengan demikian persamaan logistic regression dapat dinyatakan sebagai berikut:

$$
\begin{aligned}
\mathrm{LN} \frac{\mathrm{S}}{1-\mathrm{S}}= & 15,332-0,004 \mathrm{CAR}+0,005 \mathrm{ATTM}+0,760 \mathrm{APB}-0,123 \mathrm{PPAPAP}-0,004 \mathrm{PPAP}- \\
& \text { 1,602NPL + 0,105ROA + 0,203ROE + 0,127NIM - 0,011BOPO - 0,101LDR - } \\
& \text { 0,461GWM }
\end{aligned}
$$

Dari tabel di atas variabel CAR memiliki nilai signifikansi sebesar 0,128>0,05 yang berarti variabel CAR tidak menentukan Kesehatan Perbankan. Hal ini disebabkan karena modal yang dimiliki bank mencukupi dalam menunjang aktiva yang mengandung atau menghasilkan risiko. Hasil ini tidak konsisten dengan penelitian Almilia (2005), Aryati (2002) dan Mabruroh (2004).

Variabel ATTM memiliki nilai signifikansi sebesar 0,773>0,05 yang berarti variabel ATTM tidak menentukan Kesehatan Perbankan. Hal ini disebabkan karena modal yang dimiliki bank mencukupi dalam menunjang aktiva tetap dan inventaris. Hasil ini konsisten dengan penelitian Almilia (2005).

Variabel APB memiliki nilai signifikansi sebesar 0,224>0,05 yang berarti variabel APB tidak menentukan Kesehatan Perbankan. Hal ini disebabkan oleh kurangnya akurasi perhitungan aktiva produktif oleh bank. Hasil 
ini konsisten dengan penelitian Almilia (2005). Variabel PPAPAP memiliki nilai signifikansi sebesar 0,722>0,05 yang berarti variabel PPAPAP tidak menentukan Kesehatan Perbankan. Hasil ini konsisten dengan penelitian Almilia (2005). Variabel PPAP memiliki nilai signifikansi sebesar 0,596>0,05 yang berarti variabel PPAP tidak menentukan Kesehatan Perbankan. Hasil ini konsisten dengan penelitian Almilia (2005).

Variabel NPL memiliki nilai signifikansi sebesar 0,001<0,05 yang berarti variabel NPL menentukan Kesehatan Perbankan. Hal ini disebabkan karena kredit yang diberikan dalam hal ini hanya kredit yang diberikan kepada dana pihak ketiga tidak termasuk kredit kepada Bank lain. Hasil ini konsisten dengan Mabruroh (2004) tetapi tidak konsisten dengan hasil penelitian Almilia (2005).

Variabel ROA memiliki nilai signifikansi sebesar 0,721>0,05) yang berarti variabel ROA tidak menentukan Kesehatan Perbankan. Hal ini disebabkan karena Bank Indonesia sebagai pembina dan pengawas perbankan lebih mengutamakan nilai profitabilitas suatu bank yang diukur dengan asset yang dananya sebagai besar berasal dari dana simpanan masyarakat. Hasil ini konsisten dengan penelitian Almilia (2005) tetapi tidak konsisten dengan hasil penelitian Aryati (2002), Wilopo (2001) dan Mabruroh (2004). Variabel ROE memiliki nilai signifikansi sebesar $0,004<0,05$ yang berarti variabel ROE menentukan Kesehatan Perbankan. Hasil ini konsisten dengan penelitian Mabruroh (2004) dan Wilopo (2001) tetapi tidak konsisten dengan hasil penelitian Almilia (2005).

Variabel NIM memiliki nilai signifikansi sebesar 0,389>0,05 yang berarti variabel NIM tidak menentukan Kesehatan Perbankan. Hal ini disebabkan karena semakin besar rasio ini maka meningkatnya pendapatan bunga atas aktiva produktif yang dikelola Bank sehingga kemungkinan suatu Bank dalam kondisi bermasalah semakin kecil. Hasil ini konsisten dengan penelitian Almilia (2005) tetapi tidak konsisten dengan hasil penelitian Wilopo (2001).

Variabel BOPO memiliki nilai signifikansi sebesar 0,692>0,05 yang berarti variabel BOPO tidak menentukan Kesehatan Perbankan. Hal ini disebabkan karena adanya proporsionalitas antara biaya operasional dan pendapatan operasional. Hasil ini tidak konsisten dengan penelitian Almilia (2005) dan Wilopo (2001).

Variabel LDR memiliki nilai signifikansi sebesar 0,001<0,05 yang berarti variabel LDR menentukan Kesehatan Perbankan. Hasil ini konsisten dengan penelitian Mabruroh (2004) tetapi tidak konsisten dengan hasil penelitian Almilia (2005). Variabel GWM memiliki nilai signifikansi sebesar $0,008<0,05$ yang berarti variabel GWM menentukan Kesehatan Perbankan. Hasil ini konsisten dengan penelitian Mabruroh (2004). 


\section{PENUTUP}

Simpulan penelitian adalah NPL, ROE, LDR dan GWM merupakan faktor penentu kondisi kesehatan Bank. Sedangkan CAR, ATTM, APB, PPAPAP, PPAP, ROA, NIM dan BOPO bukan merupakan faktor penentu kondisi kesehatan Bank. Penelitian ini memiliki beberapa keterbatasan pertama, penelitian ini tidak dapat menggunakan bank publik karena banyaknya informasi yang tidak bisa didapatkan dan laporan keuangan yang kurang lengkap untuk diteliti karena tidak dipubliksikan. Kedua, faktor-faktor di luar rasio keuangan seperti faktor ekonomi (inflasi, tingkat bunga dan tingkat pengangguran). Bila faktor-faktor tersebut dapat diperoleh serta dapat diukur dengan tepat, maka akan diperoleh tingkat prediksi kesehatan bank yang lebih akurat. Ketiga, penelitian ini hanya melakukan pengukuran dengan rasio CAMEL belum menggunakan CAMELS, mungkin dengan adanya tambahan rasio akan mempengaruhi estimasi parameter regresi. Terakhir, laporan keuangan yang digunakan dalam penelitian ini didapatkan dari direktori perbankan, sedangkan dalam direktori tersebut dicantumkan dewan audit tetapi tidak mencantumkan pendapat akuntan atas laporan keuangan auditan, sehingga laporan keuangan yang digunakan sebagai data dalam penelitian ini belum tentu laporan keuangan dengan "pendapat wajar tanpa pengecualian" oleh karena itu keandalan laporan keuangan tersebut masih dapat dipertanyakan.

Berdasarkan keterbatasan di atas maka rekomendasi untuk penelitian selanjutnya adalah (1) menggunakan bank publik sebagai sampel, (2) faktor ekonomi seperti inflasi, tingkat bunga, kurs dan harga saham (untuk bank publik) sebaiknya ikut dipertimbangkan dalam penelitian, (3) melengkapi CAMEL dengan CAMELS, (4) mendapatkan informasi dari pihak Bank bersangkutan atau lembaga yang bersangkutan jangan hanya Bank Indonesia, agar mendapatkan hasil yang lebih akurat.

\section{REFERENSI:}

Bank Indonesia. 2001. Surat Edaran Bank Indonesia. Nomor 3/30/DPNP tanggal 14 Desember. Almilia, L.S. dan H. Winny. 2005. Analisa Rasio CAMEL Terhadap Prediksi Kondisi Bermasalah Pada Lembaga Perbankan Periode 2002. Jurnal Akuntansi dan Keuangan, Vol.7, no.2, hlm. 131-142.

Angelian, Liza. 2004. Perbandingan Early Warning System (EWS) untuk Memprediksi Kebangkrutan Bank Umum Indonesia. Buletin Ekonomi Moneter dan Perbankan. hlm. 461- 484.

Ariyanto, Taufik. 2004. Profit Persaingan Usaha dalam Industri Perbankan Indonesia. Perbanas Finance and Banking Journal, Vol.6, no.2, hlm. 95-108. 
Aryati, Titik dan M.N. Etty. 2002. Model Analisis CAMEL untuk Memprediksi Financial Distress Pada Sektor Perbankan yang Go Public. Jurnal Akuntansi dan Auditing Iodonesia, Vol.4, No.2, hlm. 111-130.

Aryati, Titik dan M. Hekinus. 2002. Rasio Keuangan Sebagai Prediktor Bank Bermasalah di Indonesia. Jurnal Riset Akuntansi Indonesia, Vol.5, No.2, hlm. 137-147.

Budisantoso, Totok dan T. Sigit. 2006. Bank dan Lembaga Keuangan Lain. Jakarta: Salemba Empat.

Dendawijaya, Lukman. 2003. Manajemen Perbankan. Jakarta: Graha Indonesia.

Gamayuni, R.R. 2006. Rasio Keuangan Sebagai Prediktor Kegagalan Perusahaan di Indonesia. Jurnal Bisnis dan Manajemen, Vol.3, No.1, hlm. 15-37.

Ghozhali, Imam. 2006. Aplikasi Analisis Multivariate dengan Program SPSS. Semarang: Badan Peneliti Universitas Diponegoro.

Hadad, Muliaman, Wimboh, S, Sarwedi, Hari, S dan Mohd, A. 2004. Model Prediksi Kepailitan Bank Umum di Indonesia. Jakarta: Direktorat Penelitian dan Pengaturan Perbankan.

Mabruroh. 2004. Manfaat dan Pengaruh Rasio Keuangan Dalam Analisis Kinerja Keuangan Pebankan. Benefit, Vol.8, No.1, hlm. 37-51.

Siswantoro, Dodik. 2004. Karakteristik Bank Likuidasi dan Restrukturisasi di Indonesia. Jurnal Akuntansi dan Keuangan, Vol.1, No.2, hlm. 45-62.

Surifah. 2002. Kinerja Keuangan Perbankan Swasta Nasionala Indonesia Sebelum dan Setelah Krisis Ekonomi. Jurnal Akuntansi dan Auditing Indonesia, Vol. 6, No. 2, hlm. 23-50.

Suyatno, Thomas, Azhar, A dan Y.A. Tinon. 2003. Kelembagaan Perbankan. Jakarta: Gramedia Pustaka Utama.

Swandari, Fifi. 2004. Pengaruh Perilaku Resiko dan Struktur Kepemilikan Terhadap Kebangkrutan Bank di Indonesia: Kasus Krisis Ekonomi Tahun 1997. Jurnal Ekonomi STEI, No.2, hlm. 57-72.

Trihartanto, Bambang dan K. Jarot. 2005. Penilaian Tingkat Kesehatan Perbankan Indonesia Menggunakan Fungsi Peluang Regresi Logistik. Jurnal Keuangan dan Perbankan, Vol. 7, No. 1, hlm. 37-52.

Wilopo. 2001. Prediksi Kebangkrutan Bank. Jurnal Riset Akuntansi Indonesia, Vol. 4, No. 2, hlm. 184-198. 